\title{
Evaluation of Quality of Chapaties Enriched with Jackfruit Seed Flour and Bengal Gram Flour
}

\author{
Afroza Sultana ${ }^{1}$, Md Ramim Tanver Rahman ${ }^{2}$, Monirul Islam³ ${ }^{3}$, Moshiur \\ Rahman ${ }^{4}$, Md. Abdul Alim ${ }^{5}$ \\ ${ }^{I}$ Department of Food Processing and Engineering, Chittagong Veterinary and Animal Sciences University, \\ Khulsi-4225, Chittagong, Bangladesh. \\ ${ }^{2}$ State Key Laboratory of Food Science and Technology, School of Food Science and Technology, Jiangnan \\ University, Wuxi 214122, P.R.China. \\ ${ }^{3}$ Rural Development Academy (RDA), Bogra, Bangladesh. \\ ${ }^{4}$ School of Engineering, Primeasia University, Dhaka, Bangladesh. \\ ${ }^{5}$ Department of Food Technology and Rural Industries, Bangladesh Agricultural University, Mymensingh-2202.
}

\begin{abstract}
Jackfruit seeds and bengal gram are rich of nutrients as protein, crude fibre, minerals etc. To improve the quality of chapati, jackfruit seed flour and bengal gram flour were used along with wholemeal wheat flour (atta). The aims of this study were to enrich the quality of chapaties and to check the shelf life of chapaties in ambient and refrigerated condition $\left(6^{\circ} \mathrm{C}\right)$. Four types $\left(R_{c}, R_{1}, R_{2}, R_{3}\right)$ of chapaties were prepared adding 100\% atta in control; 5, 15, 25 percent white and 10, 15, 20 percent brown jackfruit seed flour with 5, 15, 10 percent bengal gram flour respectively. The spread ratio of $R_{3}(46.25)$ was more than others. Inspite of higher spread ratio of $R_{3}$ the highest energy (324.73 kcal/100g) containing chapati was $R_{1}$ type because of its composition. The samples were packed in high density polyethylene and stored at the refrigerated and ambient temperature. The shelf life of chapaties was obtained 3 to 4 days at ambient and 30 days at refrigerated temperature. The sensory attributes of fresh chapaties were also evaluated and found the highest acceptability of $R_{1}$ sample. This study concluded that the best sample was $R_{1}$ which had higher energy level and consumer acceptability.
\end{abstract}

Keywords: Brown spermoderm, jackfruit seed flour, shelf life, spread ratio, white spermoderm.

\section{Introduction}

Chapaties are unleavened Indian flat breads made by milling whole-wheat grains into whole-wheat flour (atta) [1]. In Bangladesh, chapati is one of the commonly consumed products in the breakfast. Adding jackfruit seed flour and bengal gram flour may additionally improve the nutritional quality of the product. The word "Chappathi" is derived from Canada, origin "Chappate thatti" meaning "flattened round". Chapatis are one of the most favorite bread items in northern South Asia. Chapati is a form of roti or rotta (bread). The words are often used interchangeably. While roti or rotta refers to any flat unleavened bread, chapati is a roti made of whole wheat flour and cooked on a tava (flat skillet). Some people also add salt and/or oil to the dough. Small portions of the dough are rolled out into discs. The rolled-out dough is thrown on the preheated dry skillet and cooked on both sides. The quality characteristics of chapaties are mainly interrelated with the quality of wheat used and the processing conditions employed for converting it into flour. Flours of other cereal grains can be used in combination with wheat flour to increase the nutritional quality of the chapati. Chapaties have been prepared from whole-wheat flour adding soy flour to improve the protein content by [2]. Wholemeal wheat flour is mixed with water to prepare dough and given minimum rest period of 15-30 min, before sheeting to a thickness of about 2 to $3 \mathrm{~mm}$. The sheeted dough is thus cut into a diameter of 12 to $15 \mathrm{~cm}$ and baked on a hotplate at $220^{\circ} \mathrm{C}$ and finally puffed on a live flame for few seconds. Completing and full puffing, soft and pliable textures as well as whitish brown color with dark brown spots are some of the important attributes of good quality chapati. It is estimated that almost $90 \%$ of the total wheat produced is used for chapati production. The qualities of chapati are influenced by wheat variety composition, method of milling, storage conditions and other conditions [3]. Jackfruit seeds are fairly rich in starch [4]. The seeds may be boiled, or roasted and eaten or boiled and preserved in syrup like chestnuts. Roasted, dried seeds were ground to produce flour which was blended with wheat flour for baking [5]. To control obesity and diabetes, little efforts should be carried out through diet diversification programs. It is necessary to increase dietary fiber in the diet of vulnerable group by blending high dietary fiber commodities in the staple diet i.e. chapati to reduce the threat of glycemic indices and obesity. 
Thus the present study was aimed-

a. to enrich the quality of chapaties;

b. to evaluate the baking performance of chapaties because of adding jackfruit seed flour and bengal gram flour

c. to check the shelf life of chapaties

d. to determine the sensory attributes of chapaties

\section{Materials and Methods}

The jackfruit seeds were cleaned manually and white arils (seed coat) were manually peeled off. Seeds were lye peeled, soaked in 3 per cent sodium hydroxide solution for 3-5 minutes to remove the thin brown spermoderm which covered the cotyledons. The spermoderm layer was removed by rubbing the seeds within the hands and washing thoroughly under running water. The seeds were sliced into thin chips separately and dried at 50 to $60^{\circ} \mathrm{C}$ to constant moisture $(<13 \%)$. The dried chips were powdered in a flour mill, passed through $105 \mu$ mesh sieve and packed in polyethylene pouches and stored in a refrigerator $\left(<10^{\circ} \mathrm{C}\right)$ for further use and analysis. The raw bengal gram dal was cleaned to remove dirt and other undesirable materials. The clean bengal gram was then dried in a cabinet dryer at $60 \pm 2{ }^{\circ} \mathrm{C}$ for 4 hours. After then the dried bengal gram was ground into powder in a grinder, sieved, packaged in polythene bags and stored at room temperature for further use in the preparation of chapati. The fresh wholemeal wheat flour (ata), bengal gram, jackfruit seed and jackfruit seed flour and chapati prepared by incorporating ata, bengal gram flour, jackfruit seed flour were analyzed for moisture, ash, protein, fat, crude fibre and carbohydrate contents. The moisture, ash, protein, fat, fibre contents were determined as per the methods described by [6] [7].The carbohydrate content was determined by difference, that is by subtracting the measured moisture, ash, protein and fat content from 100 [8].

The basic formulations used for preparation of chapati are outlined in Table 1 as shown in below.

Table 1: Formulation of chapaties from composite flour

\begin{tabular}{|l|l|l|l|l|}
\hline \multirow{2}{*}{ Ingredients } & Quantity $(\mathbf{g})$ & Quantity $(\mathbf{g})$ & Quantity $(\mathbf{g})$ & Quantity $(\mathbf{g})$ \\
\cline { 2 - 5 } & Control $\left(\mathbf{R}_{\mathbf{c}}\right)$ & Recipe 1 $\left(\mathbf{R}_{\mathbf{1}}\right)$ & Recipe 2 $\left(\mathbf{R}_{\mathbf{2}}\right)$ & Recipe 3 $\left(\mathbf{R}_{\mathbf{3}}\right)$ \\
\hline Wholemeal wheat flour (Atta) & 100 & 80 & 55 & 45 \\
\hline White jackfruit seed flour & - & 5 & 15 & 25 \\
\hline Brown jackfruit seed flour & - & 10 & 15 & 20 \\
\hline Bengal gram flour & - & 5 & 15 & 10 \\
\hline Water & 60 & 60 & 60 & 60 \\
\hline Fat (Soybean oil) & 5 & 5 & 5 & 5 \\
\hline Salt (NaCl) & 1 & 1 & 1 & 1 \\
\hline Sugar & 2 & 2 & 2 & 2 \\
\hline Baking powder & 0.5 & 0.5 & 0.5 & 0.5 \\
\hline
\end{tabular}

According to the above Table all ingredients were weighed and mixed to prepare soft dough and allowed to rest for 30 mins. The dough was divided into small portions and kneaded and rolled (Thickness 0.25 $\mathrm{cm})$. The rolled sheet was cut with round chapatti cutter $(10.5 \mathrm{~cm}$ diameter). Finally baked in a preheated non sticky frying pan $\left(180-200^{\circ} \mathrm{C}\right.$ for $2-2.5$ minutes), cooled and packed in high density polyethylene bag for storing at room temperature and refrigerated temperature $\left(6^{\circ} \mathrm{C}\right)$. The observations were made at 7 days intervals for moisture content for 1 month. The spread ratio is concerned as one of the most important quality parameters of chapaties. The spread ratio was determined by the formula $\mathrm{W} / \mathrm{T}$, where $\mathrm{W}$ was the average width $(\mathrm{cm})$ and $\mathrm{T}$ was the average thickness $(\mathrm{cm})$ of the 5 chapaties after baking. The moisture content of chapaties was determined adopting [7]. Weights of each type chapaties were also determined. Sensory evaluations of all chapaties were done by taste testing panel. The taste testing panel was made up with of 10 test panelists. They were asked to evaluate color, flavor, texture and overall acceptability by a scoring rate on a 9 point hedonic scale. $9=$ Like extremely, $8=$ Like very much, $7=$ Like moderately, $6=$ Like slightly, $5=$ Neither like nor dislike, 4= Dislike slightly, $3=$ Dislike moderately, $2=$ Dislike very much and $1=$ Dislike extremely. The preference differences were evaluated by statistical analysis [9] of the data for variance and consequently Duncan's Multiple Range Test (DMRT). Procedures of the SPSS 16.0 were used for statistical analysis. Chapaties prepared from composite flour were packed in high density polyethylene bags and stored for several days at ambient temperature $\left(21\right.$ to $\left.30^{\circ} \mathrm{C}\right)$ and 1 month at refrigerated condition $\left(6^{\circ} \mathrm{C}\right)$. The observations were made at 7 days intervals for moisture content.

\section{Results and Discussions}

The proximate composition of wholemeal wheat flour, bengal gram flour and jackfruit seed flour were found as shown in Table 2 and 3. 
Table 2: Composition of wholemeal wheat flour and bengal gram flour

\begin{tabular}{|l|l|l|}
\hline Components & Wholemeal Wheat Flour $(\boldsymbol{\%})$ & Bengal Gram Flour $(\boldsymbol{\%})$ \\
\hline Moisture & 13.0 & 8.09 \\
\hline Ash & 1.3 & 3.1 \\
\hline Protein & 10.5 & 24.5 \\
\hline Fat & 0.9 & 6.1 \\
\hline Crude Fibre & 1.7 & 1.3 \\
\hline Total Carbohydrate (by difference) & 74.3 & 58.21 \\
\hline
\end{tabular}

The composition of wholemeal wheat flour under study was near about [10], who reported the nutrient content of wheat flour as follows: moisture $13.63 \%$, ash $1.15 \%$, protein $11.44 \%$, fat $0.88 \%$, and total carbohydrate $72.9 \%$. The composition of bengal gram flour under study was more or less similar to [11], who reported the nutrient content of bengal gram flour as follows: moisture $11.08 \%$, ash $0.41 \%$, protein $18.98 \%$, fat $4.96 \%$ and total carbohydrate $64.57 \%$. The differences observed in these compositions may be due to varietal differences, agro-ecological condition, fertilizer use, methods of analysis etc.

Table 3: Composition of jackfruit seed flour

\begin{tabular}{|l|l|l|}
\hline Components & $\begin{array}{l}\text { Jackfruit seed flour with brown } \\
\text { spermoderm }(\boldsymbol{\%})\end{array}$ & $\begin{array}{l}\text { Jackfruit seed flour without brown } \\
\text { spermoderm }(\boldsymbol{\%})\end{array}$ \\
\hline Moisture & 8.1 & 9.1 \\
\hline Ash & 3.92 & 2.7 \\
\hline Protein & 11.43 & 11.9 \\
\hline Crude fat & 1.98 & 1.05 \\
\hline Crude fibre & 2.87 & 1.53 \\
\hline Total carbohydrate (by difference) & 74.57 & 75.25 \\
\hline
\end{tabular}

The physical parameters like weight, diameter, thickness, color, flavor and texture of chapaties incorporated with different levels of composite flour were determined and results are presented in the Table 4.

Table 4: Effect of composite flour on the weight, width, thickness, color, flavor and texture of chapaties

\begin{tabular}{|l|l|l|l|l|l|l|l|}
\hline $\begin{array}{l}\text { Type } \\
\mathbf{s}\end{array}$ & $\begin{array}{l}\text { Weight } \\
(\mathbf{g})\end{array}$ & $\begin{array}{l}\text { Width, W } \\
(\mathbf{c m})\end{array}$ & $\begin{array}{l}\text { Thickness, T } \\
(\mathbf{c m})\end{array}$ & $\begin{array}{l}\text { Spread ratio } \\
(\mathbf{W} / \mathbf{T})\end{array}$ & Color & Flavor & Texture \\
\hline $\mathrm{R}_{\mathrm{c}}$ & 50.3 & 10.5 & 0.28 & 37.5 & $\begin{array}{l}\text { Very light } \\
\text { brown }\end{array}$ & Baked flavor & $\begin{array}{l}\text { Slightly } \\
\text { hard }\end{array}$ \\
\hline $\mathrm{R}_{1}$ & 50.1 & 10.6 & 0.29 & 36.55 & Light brown & Baked flavor & $\begin{array}{l}\text { Slightly } \\
\text { soft }\end{array}$ \\
\hline $\mathrm{R}_{2}$ & 50.5 & 10.9 & 0.27 & 40.37 & Brownish & Baked flavor & Soft \\
\hline $\mathrm{R}_{3}$ & 50.9 & 11.1 & 0.24 & 46.25 & Dark brown & Baked flavor & Soft \\
\hline
\end{tabular}

$\mathbf{R}_{\mathbf{c}}=$ Control chapati contains $\mathbf{1 0 0 \%}$ wholemeal wheat flour

$R_{1}=80 \%$ atta, $5 \%$ white jackfruit seed flour, $10 \%$ brown seed flour, $5 \%$ bengal gram flour

$\mathbf{R}_{2}=\mathbf{5 5 \%}$ atta, $15 \%$ white jackfruit seed flour, $15 \%$ brown seed flour, $15 \%$ bengal gram flour

$R_{3}=45 \%$ atta, $25 \%$ white jackfruit seed flour, $20 \%$ brown seed flour, $10 \%$ bengal gram flour

The width of the chapaties gradually increased with the incorporation of higher proportion of jackfruit seed flour. The width $(10.5 \mathrm{~cm})$ of control chapaties was minimum among all treatments. $\mathrm{R}_{3}$ had the higher width $(11.1 \mathrm{~cm})$ and weight $(50.9 \mathrm{~g})$ than that of others. It is observed that thickness of $\mathrm{R}_{1}(0.29 \mathrm{~cm})$ treated chapati was the highest followed by the control $(0.28 \mathrm{~cm})$ and $R_{3}(0.24 \mathrm{~cm})$ and $R_{2}(0.27 \mathrm{~cm})$. Spread ratio of $R_{3}$ formulation was 46.25 followed by $R_{2}$ (40.37), $R_{c}$ (37.5) and $R_{1}$ (36.55). Color of chapaties went dark brown by the addition of jackfruit seed flour compared to control. Texture of chapaties become soft by the incorporation of jackfruit seed flour. The composition of four types of chapaties is shown in Table 5.

Table 5: Composition of chapaties containing composite flour

\begin{tabular}{|l|l|l|l|l|l|l|l|}
\hline $\begin{array}{l}\text { Chapati } \\
\text { Types }\end{array}$ & Moisture (\%) & Ash (\%) & Protein (\%) & Fat (\%) & Crude Fibre (\%) & $\begin{array}{l}\text { Total Carbohydrate } \\
\text { (\%) by difference) }\end{array}$ & $\begin{array}{l}\text { Energy } \\
\text { Kcal/100g }\end{array}$ \\
\hline $\mathrm{R}_{\mathrm{c}}$ & 22.98 & 1.20 & 9.70 & 1.03 & 1.50 & 65.09 & 316.22 \\
\hline $\mathrm{R}_{1}$ & 20.70 & 1.72 & 11.63 & 1.28 & 1.79 & 64.67 & 324.73 \\
\hline $\mathrm{R}_{2}$ & 24.81 & 2.18 & 12.95 & 1.86 & 1.79 & 58.20 & 309.01 \\
\hline $\mathrm{R}_{3}$ & 22.30 & 2.35 & 12.44 & 1.67 & 1.85 & 61.24 & 317.62 \\
\hline
\end{tabular}

$\mathbf{R}_{\mathrm{c}}=$ Control chapati contains $\mathbf{1 0 0 \%}$ wholemeal wheat flour

$R_{1}=80 \%$ atta, $5 \%$ white jackfruit seed flour, $10 \%$ brown seed flour, $5 \%$ bengal gram flour

$\mathbf{R}_{2}=55 \%$ atta, $15 \%$ white jackfruit seed flour, $15 \%$ brown seed flour, $15 \%$ bengal gram flour

$R_{3}=45 \%$ atta, $25 \%$ white jackfruit seed flour, $20 \%$ brown seed flour, $10 \%$ bengal gram flour

The moisture content of chapaties containing composite flour was vary from $20.7 \%$ to $24.81 \%$ that is approximately similar to the chapaties prepared from wholemeal flour as reported by [10] as to 28.21 to 29.8 percent. Some variation may be due to baking condition during preparation. The formulation of $\mathrm{R}_{3}$ chapaties had 
the higher ash that reveals the higher mineral content. Because of using $15 \%$ of white, brown jackfruit seed flour and bengal gram flour separately the amount of protein content found to be higher above in $\mathrm{R}_{2}$ formulation than others. As bengal gram is rich in protein, so using a large portion of bengal gram flour contributed higher protein content in $\mathrm{R}_{2}$ formulation (12.95\%). Though fat content did not vary widely, $\mathrm{R}_{2}$ had the higher value $(1.86 \%)$. Bengal gram flour contains enough fat content than other flour and therefore, proportion of using of bengal gram flour increased the fat content in $\mathrm{R}_{2}$ formulation. Similar to mineral content, $\mathrm{R}_{3}$ had the more percent of crude fibre due to incorporation of $20 \%$ brown jackfruit seed flour. Because of containing more fibre in brown spermoderm of jackfruit seed, $\mathrm{R}_{3}$ had $1.85 \%$ fibre whereas $\mathrm{R}_{1}$ and $\mathrm{R}_{2}$ had similar value of $1.79 \%$ and less fibre content was found in control $(1.5 \%)$. Yet, higher proportion of protein and fat content was found in $R_{2}$ and higher portion of carbohydrate in control chapaties. $\mathrm{R}_{1}$ is the formulation which got the much more energy compared to other. The energy in $\mathrm{kcal} / 100 \mathrm{~g}$ was the highest in $\mathrm{R}_{1}$ (324.73) because of balance amounts of incorporation of flours. The color of different fungal growth was observed stored at ambient and refrigerated condition that is shown in Table 6.

Table 6: Shelf life of chapaties from composite flour at room temperature and refrigerated conditions

\begin{tabular}{|l|l|l|l|}
\hline Temperature & Sample & Shelf life (days) & Spoilage observed \\
\hline \multirow{3}{*}{ Room temp. $\left(21\right.$ to $\left.30^{\circ} \mathrm{C}\right)$} & $\mathrm{R}_{\mathrm{c}}$ & 3 & Blackish fungal spot found \\
\cline { 2 - 4 } & $\mathrm{R}_{1}$ & 3 & More blackish spot \\
\cline { 2 - 4 } & $\mathrm{R}_{2}$ & 4 & Grayish spot found \\
\cline { 2 - 4 } & $\mathrm{R}_{3}$ & 3 & Black spot \\
\hline \multirow{3}{*}{$\begin{array}{l}\text { Refrigerated condition } \\
\left(6^{\circ} \mathrm{C}\right)\end{array}$} & $\mathrm{R}_{\mathrm{c}}$ & 30 & Blackish spot \\
\cline { 2 - 4 } & $\mathrm{R}_{1}$ & 30 & Blackish spot \\
\cline { 2 - 4 } & $\mathrm{R}_{2}$ & 29 & Blackish and grayish spot \\
\cline { 2 - 4 } & $\mathrm{R}_{3}$ & 30 & Black fungal spot \\
\hline
\end{tabular}

$\mathbf{R}_{\mathrm{c}}=$ Control chapati contains $\mathbf{1 0 0 \%}$ wholemeal wheat flour

$R_{1}=80 \%$ atta, $5 \%$ white jackfruit seed flour, $10 \%$ brown seed flour, $5 \%$ bengal gram flour

$\mathbf{R}_{2}=\mathbf{5 5 \%}$ atta, $\mathbf{1 5 \%}$ white jackfruit seed flour, $15 \%$ brown seed flour, $15 \%$ bengal gram flour

$R_{3}=45 \%$ atta, $25 \%$ white jackfruit seed flour, $20 \%$ brown seed flour, $10 \%$ bengal gram flour

In general, the shelf life of chapaties prepared from different flour may be 3 to 4 days at room temperature while approximately 30 days at refrigerated condition. Actually, the poor shelf life of chapaties had due to their water activity value. Mollik (2006) identified that the water activity of chapaties varied from 0.55 to 0.67 at room temperature prepared from wholemeal wheat flour with preservatives. However, the appearance of different fungus observed mainly black in color. But because of incorporation of bengal gram largely flour, grayish color was identified in $\mathrm{R}_{2}$ type chapaties. As no preservative was added in chapaties, so the shelf life was not long which was observed. The moisture content of different chapaties was determined during storage period that is shown in Table 7.

Table 7: Moisture content of different chapaties during storage period

\begin{tabular}{|l|l|l|l|l|}
\hline \multirow{2}{*}{$\begin{array}{l}\text { Storage } \\
\text { days) }\end{array}$} & \multicolumn{2}{|l}{$\mathrm{M.C}(\%)$ at room temperature $(\mathbf{2 1 - 3 0} \mathbf{0} \mathbf{C})$} & $\begin{array}{l}\text { M.C }(\%) \text { at refrigerated temperature } \\
\left(\mathbf{6}^{\mathbf{0}} \mathbf{C}\right)\end{array}$ \\
\cline { 2 - 5 } & $\mathrm{R}_{\mathrm{c}}$ & $\mathrm{R}_{3}$ & $\mathrm{R}_{\mathrm{c}}$ & $\mathrm{R}_{3}$ \\
\hline 0 & 22.98 & 22.3 & 22.98 & 22.3 \\
\hline 3 & 22.71 & 21.82 & 23.01 & 22.52 \\
\hline 7 & - & - & 23.13 & 22.57 \\
\hline 14 & - & - & 23.34 & 22.78 \\
\hline 21 & - & - & 23.59 & 22.93 \\
\hline 28 & - & - & 23.71 & 23.45 \\
\hline 30 & - & - & 23.93 & 23.71 \\
\hline
\end{tabular}

M.C= Moisture Content

$\mathbf{R}_{\mathrm{c}}=$ Control chapati contains $\mathbf{1 0 0 \%}$ wholemeal wheat flour

$R_{3}=45 \%$ atta, $25 \%$ white jackfruit seed flour, $20 \%$ brown seed flour, $10 \%$ bengal gram flour

During storage period the moisture content was gradually decreased from $22.98 \%$ to $22.71 \%$ for control and $22.3 \%$ to $21.82 \%$ for $\mathrm{R}_{3}$ sample at room temperature. On the other hand, in refrigerated condition moisture content was increased slowly for both samples as 22.98 to 23.93 and 22.3 to 23.71 percent for control and $\mathrm{R}_{3}$ sample respectively. This might be because of removal of moisture content at high temp. $\left(21\right.$ to $\left.30^{\circ} \mathrm{C}\right)$ and very high humidity in refrigerated condition resulted in the increase of moisture content as well. The results are near about similar to [10] who reported decreasing moisture content at room temperature and increasing moisture content at refrigerated condition for chapaties prepared from atta and preservatives as glycerol, sodium acid pirophosphates, calcium propionate, sorbic acid, GMS and potassium sorbate.

The chapaties prepared from composite flour were subjected to sensory evaluation by a panel of 10 judges. The mean scores of color, flavor, texture and overall acceptability are presented in Table 8 . 
Table 8: Mean sensory scores of different chapaties

\begin{tabular}{|l|l|l|l|l|}
\hline \multirow{2}{*}{ Types of Chapati } & \multicolumn{4}{|c|}{ * Mean Scores of Sensory Attributes } \\
\cline { 2 - 5 } & Color & Flavor & Texture & Overall Acceptability \\
\hline $\mathrm{R}_{\mathrm{c}}$ & $8.0^{\mathrm{a}}$ & $7.9^{\mathrm{a}}$ & $7.7^{\mathrm{a}}$ & $7.7^{\mathrm{ab}}$ \\
\hline $\mathrm{R}_{1}$ & $7.6^{\mathrm{ab}}$ & $7.8^{\mathrm{a}}$ & $7.9^{\mathrm{a}}$ & $7.9^{\mathrm{a}}$ \\
\hline $\mathrm{R}_{2}$ & $7.1^{\mathrm{b}}$ & $7.0^{\mathrm{b}}$ & $7.0^{\mathrm{b}}$ & $7.3^{\mathrm{b}}$ \\
\hline $\mathrm{R}_{3}$ & $6.4^{\mathrm{c}}$ & $6.9^{\mathrm{b}}$ & $6.7^{\mathrm{b}}$ & $6.7^{\mathrm{c}}$ \\
\hline LSD & 0.95 & 0.95 & 0.95 & 0.95 \\
\hline
\end{tabular}

*Means with different superscripts within a column are significantly different and the same superscripts do not significantly different at $\mathbf{p}<0.05$.

$\mathbf{R}_{\mathrm{c}}=$ Control chapati contains $\mathbf{1 0 0 \%}$ wholemeal wheat flour

$\mathbf{R}_{1}=80 \%$ atta, $5 \%$ white jackfruit seed flour, $10 \%$ brown seed flour, $5 \%$ bengal gram flour

$\mathbf{R}_{2}=55 \%$ atta, $15 \%$ white jackfruit seed flour, $15 \%$ brown seed flour, $15 \%$ bengal gram flour

$R_{3}=45 \%$ atta, $25 \%$ white jackfruit seed flour, $20 \%$ brown seed flour, $10 \%$ bengal gram flour

The one way analysis of variance indicated that all these sensory attributes were significantly $(\mathrm{p}<0.05)$ different and thus the chapaties showed varied degree of acceptability in terms of color, flavor, texture and overall acceptability.

The DMRT tests revealed that the control sample secured the highest value (8.0) for color preference but it was not statistically different from $R_{1}$ (7.6) sample. $R_{3}(6.4)$ formulation was also different from other 3 samples. For flavor, control sample (7.9) and $R_{1}$ (7.8) were not statistically different from each other as like as $R_{2}$ (7.0) and $R_{3}$ (6.9). On the other hand, control and $R_{1}$ samples were approximate similar texture after preparation. Like the previous samples $\mathrm{R}_{2}$ and $\mathrm{R}_{3}$ samples were not significantly different from each other as the values are 7.0 and 6.7 respectively. However, the overall acceptability was highest for $R_{1}$ sample. $R_{1}$ secured the highest marks as 7.9. It indicates that $\mathrm{R}_{1}$ was mostly acceptable to the consumer though control sample had no difference as it obtained 7.7. Besides, $R_{2}$ (7.3) sample was different from $R_{1}$. However, no difference exists to control sample. Interestingly, the lowest acceptance found for $\mathrm{R}_{3}(6.7)$ sample like the color preference.

With the help of DMRT mean scores of color, flavor, texture and overall acceptability a bar diagram is drawn in the Figure 1, from which the most acceptable sample can be identified clearly.

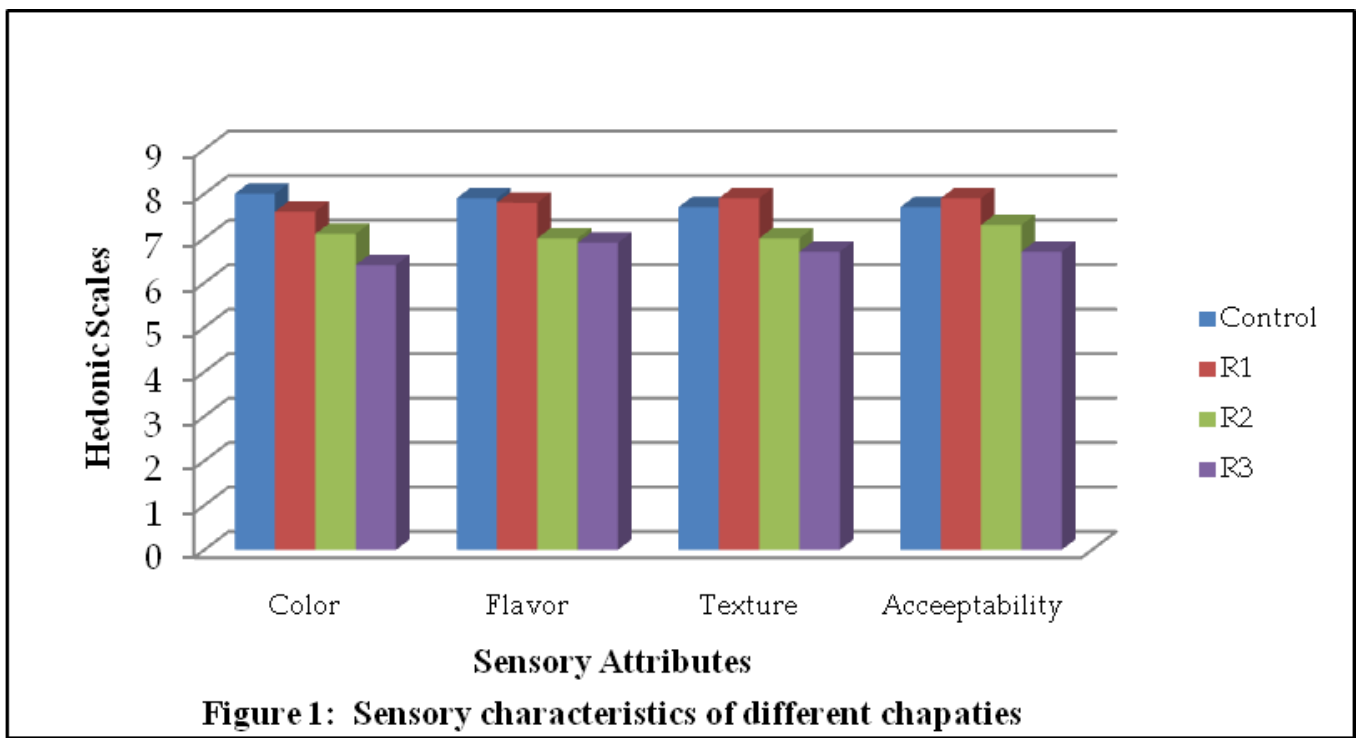

It is clear from the above Figure that $\mathrm{R}_{1}$ sample is the best one among all concerning to the sensory attributes followed by control then $R_{2}$ and then $R_{3}$. The more the incorporation of the jackfruit seed flour and the bengal gram flour the poorer of the sensory characteristics of chapaties from consumer.

\section{Conclusion}

Since no preservative was added to chapaties, it stayed good only 3 to 4 days at ambient and 30 days at refrigerated condition. This study concludes that chapatti containing $80 \%$ atta, $5 \%$ white jackfruit seed flour, $10 \%$ brown seed flour, 5\% bengal gram flour was the best among 3 types of samples because of its higher calorific value and sensory acceptability. Due to incorporation of higher jackfruit seed flour the acceptability was decreased. To improve the nutritional values some fortifications like vitamins, minerals can be added into chapaties. The further studies can be expanded by adding different preservatives with observing the storage 
characteristics of chapaties. Some focuses can also be given in jackfruit seed flour by incorporating the flour in other popular food items.

\section{Acknowledgements}

The authors are greatly indebted to the Bangladesh Agricultural University, Mymensingh authority for providing facilities to complete the research. The authors cannot repay the debts of their families who sacrificed their happiness for their higher studies.

\section{References}

[1]. H.S. Gujral and A. Pathak, Effect of different additives on mixograph and bread making properties of Indian wheat flour, Journal of Food Engineering, 55, 2002, 173-179.

[2]. A.A. Vadnerkar, Soluble fiber and resistant starch components in some Indian and Canadian Wheat varieties and in a wheat-soy product- chapati, Human Nutrition, Foods and Exercise. Blacksburg, Virginia, M.S. Thesis, 2004.

[3]. M.N. Safdar, K. Naseem, N. Siddiqui, M. Amjad, T. Hammed, S. Khalil, Quality evaluation of different wheat varieties for the producton of unleavened flat bread (chapatti), Pakistan Journal of Nutrition, 8, 2009, 1773-1778.

[4]. A. Singh, S. Kumar, I.S. Singh, Functional properties of jackfruit seed flour. Lebensmittel - Wissenscheft Technolology, 24, 1991, 373-4.

[5]. S. Airani, Nutritional quality and value addition to jackfruit seed flour, Department of Food Science and Nutrition, University of Agricultural Science, Dharwad, M.S. Thesis, 2007.

[6]. S. Ranganna, Hand Book of Analysis of Quality Control for Fruit and Vegetable Products (2 ${ }^{\text {nd }}$ Ed. Tata McGraw Hill Publication Co. Ltd. New Delhi, 2002).

[7]. AOAC, Official Methods of Analysis, Association of Official Analytical Chemists (15th Edition, Washington, D. C. 2004)

[8]. D. Pearson, The Dictionary of Nutrition and Food Technology (5th Ed. Butterwarth publication, London, 1976).

[9]. SPSS Statistical Programme for Social Science. Vesion 16.0.

[10]. M. Mollik, Processing and preservation of chapattis from wholemeal flour, Department of Food Technology and Rural Industries, Bangladesh Agricultural University, Mymensingh, M.S. Thesis, 2006.

[11]. J.S. Jothi, A. Sultana, M.B. Monju, A Study on the preparation of gluten free sweet biscuits from composite flour, Department of Food Technology and Rural Industries, Bangladesh Agricultural University, Mymensingh, Project report, 2012. 